\section{$\checkmark$ Research Square}

Preprints are preliminary reports that have not undergone peer review.

They should not be considered conclusive, used to inform clinical practice, or referenced by the media as validated information.

\title{
Effect of the New Zero-Tolerance Drinking and Driving Law on Hospital Admissions Due to Road Traffic Accidents in Brazil: an Interrupted Time Series Study From 2008 to 2019 Short Title New Zero-tolerance Drinking and Driving Law on Hospitalization in Brazil
}

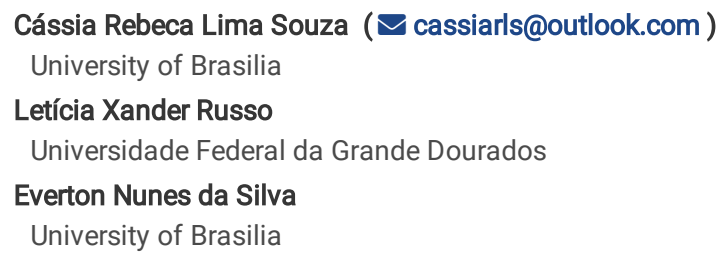




\section{Abstract}

We investigated the effect of the new zero-tolerance drinking and driving law (Law 12760) on hospital admissions due to road traffic accidents in Brazil by using interrupted time series from 2008 to 2019. We used ICD-10 codes for land transport accidents (V00-V89). The hospitalization rate was calculated per 100,000 inhabitants. The sources were the Hospital Information System and the Brazilian Institute for Geography and Statistics. For Brazil, the hospitalization rate decreased by $0.400841(\mathrm{p}=0.052 ; 95 \% \mathrm{Cl}-0.8060128$ to -0.0043307 ) in the first month of the intervention (December 2012 ), followed by a significant change in the hospitalization trend. Compared to the period prior to the intervention, the monthly trend was reduced by 0.048215 ( $\mathrm{p}<0.01 ; 95 \% \mathrm{Cl} 0.0614524$ to 0.0349775 ) in the post period. These results stand in agreement with subgroup analyses for the Brazilian regions, although North and Northeast regions did not immediately reduce hospitalization rates (level change). Our results suggested that 436,581 hospitalizations for land transport accidents were averted by the new zero-tolerance drinking and driving law from Dec. 2012 to Dec. 2019 in Brazil.

\section{Introduction}

Road traffic injuries are a global health problem, particularly for males, young people and those living in low- and middle-income countries (1-4). To achieve the target of reducing road traffic deaths and injuries by $50 \%$ by 2020 (5), the United Nations has urged local governments to adopt multiple strategies, including enforcement of traffic laws $(6,7)$. According to the World Health Organization, 176 countries reported having a drink-driving law at the national level (8). When these laws are combined with visible and rapid enforcement, they seem to effectively reduce alcohol-related crashes and deaths $(9,10)$.

Since 2008, Brazil has adopted a zero-tolerance drinking and driving law, by which motor vehicle drivers under any influence of alcohol are subjected to penalties such as larger fines, longer licence suspension, vehicle seizure and imprisonment (11). However, under Law 12760, from December 2012, zerotolerance drinking and driving law reached its higher effectiveness in terms of enforcement, particularly by increasing the use of sobriety checkpoints and including other evidence to prove drivers' intoxication (driver's appearance and actions at the scene). There is evidence on zero-tolerance drinking and driving law on mortality rate due to road traffic accident (12-14), but not on hospitalization rate. Investigating the avert hospitalizations due to stricter drink driving law (if any) can lead to some light on the potential benefit to the health system, such as reallocation of hospital beds to other causes and reduction of hospital expenditures owing to road traffic accidents.

Our study aimed to first estimate the effect of the new zero-tolerance drinking and driving law (Law 12760) on hospital admissions due to road traffic accidents in Brazil by using a quasi-experimental approach through interrupted time series from 2008 to 2019 . Then, we used these estimates to predict the averted hospitalizations owing to the new zero-tolerance drinking and driving law from December 2012 to December 2019.

\section{Methods Study setting}

Brazil ranks fifth in the world in total area (8.51 million $\mathrm{km}^{2}$ ) and sixth in population size (212 million inhabitants) $(15)$. In 2019, Brazil had 75,800 and 10,400 $\mathrm{km}$ of paved and unpaved roads, respectively (16). There were 107,948,371 vehicles operating on roads across the country in 2020 , with cars and motorcycles representing $58.74 \%$ and $22.10 \%$, respectively (17). Since 1988 , Brazil has provided universal healthcare coverage free of charge at the point of service through the Unified Health System (SUS, acronym in Portuguese). SUS delivers primary and specialty care, including health promotion and prevention, diagnosis, and treatment at any lifespan need (18). Approximately $75 \%$ of the Brazilian population has access to healthcare only through SUS, since $25 \%$ have private health insurance (19).

\section{Introduction of laws against drinking and driving in Brazil}

The first attempt to regulate drinking and driving in Brazil was in 1997, with Law 9503 from the 23rd of September 1997, by which the Brazilian Traffic Code (Código de Trânsito Brasileiro) was created. Under this law, the blood alcohol concentration (BAC) limit was $0.6 \mathrm{~g} / \mathrm{dl}$. Levels higher than this limit would result in fine vehicle retention, driver licence suspension, and imprisonment. However, the effectiveness of law was low. In 2008, it enacted the zero-tolerance drinking and driving law (Lei Seca), Law 11705, from the 19th of June 2008, lowering the BAC limit to $0.0 \mathrm{~g} / \mathrm{dl}$ and adding the suspension of the driver's licence for 12 months, imprisonment for blood alcohol concentration over $6 \mathrm{dg} / \mathrm{L}$, fine, and vehicle retention whether the driver's BAC was over the legal limit (12). To test intoxication, the traffic agent may ask the driver to perform a breath test (breathalyzer) or a blood test. However, the Justice assured the right of drivers to refuse a breathalyzer test based on the Pact of San Jose, invoking "the right not to be compelled to be a witness against himself or to plead guilty", which substantially reduced the law's effectivity (20-22). In 2012, Brazil adopted a hard-line stance against those caught driving under the influence of alcohol above the legal limit, called the new zero-tolerance drinking and driving law. Law 12760 was enacted on the 20th of December 2012, which keeps the previous restrictions (BAC limit to $0.0 \mathrm{~g} / \mathrm{dl}$, suspension of driver licence for 12 months, imprisonment, fine [increased by 2 -fold], and vehicle retention). However, this law has also included the officers' observations in the report as evidence of intoxication, i.e., the driver's appearance and actions at the scene can also be used as concrete evidence of intoxication. Other evidence has also been used, such as witnesses and videos. After 2012, there was also an increasing use of sobriety checkpoints to identify drinking and driving by systematically and randomly stopping drivers for the assessment of alcohol impairment. This strategy has also increased the perceived risk of arrest for alcohol-impaired driving (23). Table 1 shows the main characterization for each drinking and driving law. 
Table 1

Characteristics of the main regulation on drinking and driving law in Brazil

\begin{tabular}{|c|c|c|c|}
\hline \multirow[t]{2}{*}{ Characterization } & Law 9508 & Law 11705 & Law 12760 \\
\hline & 1997 & 2008 & 2012 \\
\hline $\begin{array}{l}\text { Blood alcohol } \\
\text { concentration }\end{array}$ & $>6 \mathrm{dg} / \mathrm{L}$ & Any blood alcohol level & Any blood or breath alcohol level \\
\hline Penalty & $\begin{array}{l}\text { Considered a very-serious infraction } \\
+ \\
\text { Fine of } 5 \text {-fold the reference-value } \\
+ \\
\text { Temporary driver's licence suspension } \\
\text { (without defining the period of suspension) } \\
+ \\
\text { Vehicle retention }\end{array}$ & 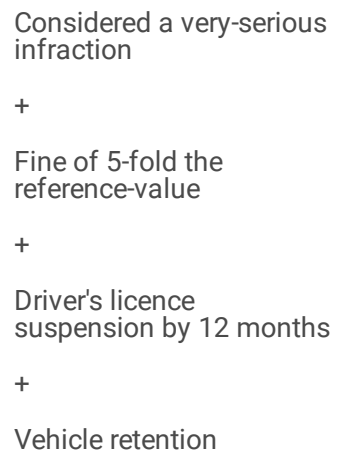 & $\begin{array}{l}\text { Considered a very-serious infraction } \\
+ \\
\text { Fine of } 10 \text {-fold the reference-value } \\
+ \\
\text { Driver's licence suspension by } 12 \text { months } \\
+ \\
\text { Vehicle retention }\end{array}$ \\
\hline Fine & $\begin{array}{l}\mathrm{R} \$ 1,467.35 \\
(=\operatorname{lnt} \$ 653.03)\end{array}$ & $\begin{array}{l}\mathrm{R} \$ 1,467.35 \\
(=\operatorname{lnt} \$ 653.03)\end{array}$ & $\begin{array}{l}\mathrm{R} \$ 2,934.70 \\
(=\operatorname{lnt} \$ 1,306.05)\end{array}$ \\
\hline Prison & $\begin{array}{l}\text { Imprisonment from } 6 \text { to } 36 \text { months, since it } \\
\text { was proved that the driver was under } \\
\text { influence of alcohol and posed a significant } \\
\text { threat to others. It was hard to prove it based } \\
\text { on the law }\end{array}$ & $\begin{array}{l}\text { Imprisonment from } 6 \text { to } \\
36 \text { months for blood } \\
\text { alcohol concentration } \\
\text { over } 6 \mathrm{dg} / \mathrm{L} \text {. Driver could } \\
\text { refuse to be tested }\end{array}$ & $\begin{array}{l}\text { Imprisonment from } 6 \text { to } 36 \mathrm{months} \text { for blood alcohol } \\
\text { concentration over than } 6 \mathrm{dg} / \mathrm{L} \text { or breath alcohol } \\
\text { concentration over than } 0.3 \mathrm{mg} / \mathrm{L} \text {. Whether the driver } \\
\text { refused to be tested, other evidence can be used } \\
\text { (witness, videos, etc.) }\end{array}$ \\
\hline
\end{tabular}

Source: Brazilian Traffic Code (24). Note: We used the reference value currently in effect in Brazil (R\$ 293.47) and the 2019 purchasing power parity - PPP conversion factor of 2.247 from the World Bank.

\section{Variables and sources}

Our variable of interest is the rate of hospitalization for land transport accidents per 100,000 inhabitants. We used the Hospital Information System (SIH/SUS) (25) and the Brazilian Institute of Geography and Statistics (IBGE) (15) to collect monthly data on hospitalizations and population size, respectively. We used the 10th revision of the International Classification of Diseases (ICD-10) codes for external causes of morbidity related to land transport accidents (V00-V89). The rate of hospitalization was calculated for Brazil, but we also stratified this variable by Brazilian region (north, northeast, middle-west, southeast and south), sex (male and female), and age group (0-4; 5-9; 10-14; 15-19; 20-29; 30-39; 40-49; 50-59; 60-69; 70-79; and 80+).

\section{Statistical analyses}

We used interrupted time series to estimate the effect of new zero-tolerance drinking and driving laws on the rate of hospitalizations for land transport accidents in Brazil. Interrupted time series analysis is a quasi-experimental approach by which causal effects are estimated based on the pre- and postintervention periods using regression modeling (26). Pre- and postintervention were defined based on the period before (Jan/2008 to Nov/2012) and after exposure to Law 12760 was enacted (Dec/2012 to Dec/2019), with data frequency per month.

We used the Cumby-Huizinga test to investigate residual autocorrelation (27), by which we identified autocorrelation at lag 3 but not at any higher lag orders (Table S1, supplementary material). Thus, our initial model specifying lag (3) should correctly account for this autocorrelation. Moreover, we used ordinary least square regression with Newey-West standard errors to handle autocorrelation and potential heteroskedasticity. Excel was used for organizing data and performing descriptive statistics, and STATA 14.2 was used for regression analyses using the ACTEST package.

We also calculated the averted hospitalizations for land transport accidents after the introduction of the new zero-tolerance drinking and driving law. We used the initial estimated trend to forecast the number of hospitalizations in a scenario of nonintervention (Law 12760) from November 2012 to December 2019. The averted hospitalizations were calculated by subtracting the forecast values from the predicted values (model considering the intervention). To calculate the hospitalization cost averted by the law, we considered the average reimbursement fees for hospitalization cause-related to land transport accident in 2019 (R\$ 1,263.46) and the 2019 purchasing power parity - PPP - conversion factor of 2.247 from the World Bank. To calculate the hospital days averted, we considered the 2008-2019 average length of stay of 6.1 days per hospitalization.

\section{Sensitivity analyses}

We also performed sensitivity analyses on the starting point of our time series and our exposure (the new-zero tolerance drinking and driving law). Based on visual inspection, the first two months of our time series (January and February 2008) were outliers compared with the following months. As interrupted time series rely on ordinary least squares (OLS), which minimizes the sum of squared residuals (28), the estimates are sensitive to outliers. We dropped the first two months and considered an alternative period (from Mar/2008 to Nov/2019). Although Law 12760 was enacted on 20th December 2012, it could have some delay in terms of its implementation. To take this scenario into account, we considered the implementation of the law in January or February 2013 . We also combined the two sensitivity analyses. 


\section{Ethics clearance}

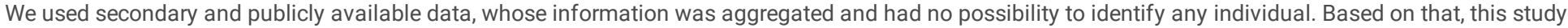
did not have to be submitted to the Research Ethics Committee, in accordance with Resolution 510/16 of the Brazilian National Health Council(29).

\section{Results}

In the period analysed (2008-2019), SUS performed 12,566,104 hospitalizations for external causes. Of them, 1,937,064 (15\%) were cause-related to land transport accidents, with an average of 13,453 per month. The hospitalization rate for land transport accidents increased from 49.7 to 91.5 per 100,000 inhabitants between 2008 and 2019 (Fig. 1).

All age groups increased the hospitalization rate for land transport accidents from 2008 to 2019 . People from the 20-29 age group ranked first in the hospitalization rate for land transit accidents during the whole period investigated. However, the 40-49 age group presented the highest growth, with an increase of $114.0 \%$ between 2008 and 2019 (Table 2).

Table 2

Hospitalization rate for land transport accident stratified by age group from 2008 to 2019 , Brazil

\begin{tabular}{|c|c|c|c|c|c|c|c|c|c|c|c|c|c|}
\hline \multirow[t]{2}{*}{ Age group } & \multicolumn{12}{|l|}{ Year } & \multirow{2}{*}{$\begin{array}{l}\text { Growth } \\
2008-2019\end{array}$} \\
\hline & 2008 & 2009 & 2010 & 2011 & 2012 & 2013 & 2014 & 2015 & 2016 & 2017 & 2018 & 2019 & \\
\hline $0-4$ & 12.7 & 17.7 & 18.4 & 18.2 & 18.3 & 20.4 & 18.9 & 16.9 & 16.3 & 16.8 & 15.9 & 15.2 & $20.0 \%$ \\
\hline $5-9$ & 23.2 & 30.1 & 31.9 & 30.9 & 31.4 & 31.4 & 29.1 & 27.2 & 25.9 & 24.7 & 23.6 & 24.5 & $5.4 \%$ \\
\hline $10-14$ & 28.0 & 34.9 & 38.5 & 39.1 & 39.1 & 41.0 & 39.3 & 36.7 & 35.6 & 35.4 & 33.0 & 31.8 & $13.6 \%$ \\
\hline $15-19$ & 62.7 & 77.9 & 89.6 & 100.5 & 105.3 & 114.0 & 118.8 & 115.2 & 114.2 & 112.6 & 105.4 & 105.2 & $68.0 \%$ \\
\hline $20-29$ & 83.4 & 107.2 & 127.1 & 132.0 & 132.9 & 139.4 & 142.9 & 142.8 & 149.0 & 149.8 & 150.0 & 159.4 & $91.0 \%$ \\
\hline $30-39$ & 59.7 & 77.6 & 95.5 & 98.8 & 100.7 & 107.5 & 110.5 & 109.6 & 113.8 & 111.9 & 115.5 & 119.5 & $100.2 \%$ \\
\hline $40-49$ & 49.3 & 64.2 & 76.8 & 80.5 & 84.2 & 91.3 & 940 & 94.6 & 97.8 & 96.3 & 98.8 & 105.5 & $114.0 \%$ \\
\hline $50-59$ & 41.3 & 53.9 & 62.2 & 65.6 & 68.1 & 72.8 & 773 & 76.4 & 78.6 & 80.1 & 83.8 & 87.1 & $110.9 \%$ \\
\hline $60-69$ & 40.3 & 49.7 & 56.1 & 56.6 & 61.4 & 64.6 & 63.8 & 60.8 & 62.3 & 63.5 & 62.5 & 66.5 & $65.0 \%$ \\
\hline 70-79 & 45.7 & 54.9 & 60.0 & 60.4 & 63.8 & 65.6 & 65.0 & 63.2 & 59.5 & 58.0 & 59.3 & 60.5 & $32.3 \%$ \\
\hline $80+$ & 51.7 & 65.6 & 71.0 & 64.9 & 65.1 & 70.5 & 69.8 & 61.5 & 58.3 & 58.3 & 56.9 & 59.7 & $15.6 \%$ \\
\hline
\end{tabular}

Males accounted for approximately $73 \%$ of all hospitalizations cause-related to land transport accidents in the period analysed. From 2008 to 2019 , both sexes presented an increase of approximately $85 \%$ in the hospitalization rate per 100,000 inhabitants, taking into account the entire county (Table 3 ).

Table 3

Hospitalizations (absolute and rate) for land transport accidents stratified by sex from 2008 to 2019 , Brazil.

\begin{tabular}{|lllll|}
\hline Year & Men & Woman & \multicolumn{2}{l}{ Hospitalization rate per 100,000 } \\
\cline { 5 - 5 } & $\mathbf{N}$ & $\mathbf{N}$ & Men & Woman \\
\hline 2008 & 74,796 & 20,366 & 78.9 & 21.1 \\
\hline 2009 & 96,074 & 27,429 & 100.3 & 28.1 \\
\hline 2010 & 114,406 & 31,660 & 118.3 & 32.0 \\
\hline 2011 & 120,487 & 33,145 & 123.4 & 33.2 \\
\hline 2012 & 124,778 & 34,438 & 126.7 & 34.2 \\
\hline 2013 & 133,562 & 37,243 & 134.5 & 36.6 \\
\hline 2014 & 137,924 & 38,083 & 137.7 & 37.1 \\
\hline 2015 & 137,062 & 37,771 & 135.8 & 36.5 \\
\hline 2016 & 142,007 & 38,436 & 139.6 & 36.8 \\
\hline 2017 & 141,801 & 39,333 & 138.4 & 37.4 \\
\hline 2018 & 143,407 & 40,043 & 139.0 & 37.8 \\
\hline 2019 & 151,102 & 41,711 & 145.5 & 39.1 \\
\hline
\end{tabular}

Table 4 shows the regression estimates for the hospitalization rate for land transport accidents per 100,000 inhabitants in Brazil and its regions. For Brazil, the initial hospitalization rate was estimated at 4.165953 per 100,000 inhabitants (January 2008). In the period prior to the introduction of the new zero-tolerance 
drinking and driving law, the trend sharply increased, with an increase of 0.054758 per 100,000 inhabitants per month $(p<0.01 ; 95 \% \mathrm{Cl} 0.0419406$ to 0.0675755). After the intervention was implemented (December 2012), the hospitalization rate decreased by 0.400841 per 100,000 inhabitants in the first month ( $p=0.052 ; 95 \% \mathrm{Cl}-0.8060128$ to -0.0043307 ). In the following months, the monthly trend of hospitalization rate increased by 0.0065 ( $p<0.01 ; 95 \% \mathrm{Cl}$ 0.0035 to 0.0096 ), indicating a weaker upward trend (or -0.0482 in relation to the trend in the period prior to the intervention). Figure 2 (a) shows the hospitalization rate for land transport accidents before and after the intervention.

Table 4

Results from the interrupted time series regression for Brazil and regions, 2008-2019

\begin{tabular}{|c|c|c|c|c|c|c|}
\hline Variables & Brazil & North & Northeast & Southeast & South & Mid-west \\
\hline \multirow[t]{2}{*}{ Time } & 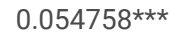 & $0.0526151^{\star \star \star *}$ & $0.0619794^{\star \star \star}$ & $0.0455077^{* \star *}$ & $0.0565731^{\star \star \star}$ & $0.0800397 * \star \star$ \\
\hline & $(0.0064831)$ & $(0.0069301)$ & $(0.0073732)$ & $(0.0072904)$ & $(0.0052262)$ & $(0.0160402)$ \\
\hline \multirow[t]{2}{*}{ Level } & $-0.400841^{\star \star *}$ & 0.2184163 & 0.1109826 & $-0.4344186^{\star}$ & $-0.7082692^{\star \star \star}$ & $-2.208351^{* * *}$ \\
\hline & $(0.2029371)$ & $(0.3197663)$ & $(0.2721336)$ & $(0.2370381)$ & $(0.1884518)$ & $(0.5667303)$ \\
\hline \multirow[t]{2}{*}{ Trend } & $-0.048215^{\star \star \star}$ & $-0.0193178^{\star *}$ & $-0.0570121^{\star \star \star}$ & $-0.0472338^{\star \star *}$ & $-0.0556164^{\star \star \star}$ & $-0.0426279 * *$ \\
\hline & $(0.0066955)$ & $(0.008758)$ & $(0.0081061)$ & $(0.0076535)$ & $(0.0057194)$ & $(0.0176499)$ \\
\hline \multirow[t]{2}{*}{ Constant } & $4.165953^{\star \star \star}$ & $2.310172^{\star \star \star}$ & $3.572928 * \star \star$ & $5.070214^{\star \star \star}$ & $3.344445^{\star \star \star}$ & $4.91043^{\star \star \star *}$ \\
\hline & $(0.2305902)$ & $(0.2462093)$ & $(0.2551009)$ & $(0.2572111)$ & $(0.2016175)$ & $(0.5748081)$ \\
\hline Observation & 144 & 144 & 144 & 144 & 144 & 144 \\
\hline \multicolumn{7}{|c|}{ Standard errors in parentheses: } \\
\hline & & & & & & \\
\hline
\end{tabular}

The zero-tolerance drinking and driving law seems to play a similar role in the mid-west, southeast and south regions as it did in Brazil as a whole (Fig. 2a, 2d, $2 \mathrm{e}$ and $2 \mathrm{f}$ ). In the north and northeast, we did not identify a significant reduction in the hospitalization rate immediately after Law 12760 was enacted. Although there was no change in the hospitalization level, the annual trend coefficient was statistically significant and negative, suggesting a weaker upward trend after the new zero-tolerance drinking and driving law (Fig. 2b and 2c).

In general, estimates from sensitivity analyses suggested similar results to the base model, except for the coefficient "level" from North and Northeast Brazil, which did not reach statistical significance at the $5 \%$ level in any specification. North also did not reach statistical significance in the "trend" variable in two specifications (sensitivity analyses 4 and 5) (Supplementary material, Table S2).

Our results suggested that 436,581 hospitalizations for land transport accidents were averted by the new zero-tolerance drinking and driving law from Dec. 2012 to Dec. 2019 in Brazil. This means an avoidable cost of Int\$ 245.48 million for the same period. Additionally, avoidable hospitalizations would allow the reallocation of 2,663,144 days of hospitalization in SUS in a 7-year period. Taking the worst scenario from the sensitivity analysis, the results would be 312,953 hospitalizations averted, 1,909,013 hospital days averted, and Int\$ 175.97 million averted (Table 5).

Table 5

Predicted hospitalizations, hospital days and costs averted by the new zero-tolerance drinking and driving law, Brazil.

\begin{tabular}{|c|c|c|c|}
\hline Model & Number of hospitalizations averted & Hospital days averted & Costs averted (Int\$, in million PPP) \\
\hline Base model & 436,581 & $2,663,144$ & 245.48 \\
\hline \multicolumn{4}{|l|}{ Period (Jan/08 - Dec/19); exposure (Dec/2012) } \\
\hline Sensitivity analysis 1 & 415,396 & $2,533,916$ & 233.57 \\
\hline \multicolumn{4}{|l|}{ Period (Jan/08 - Dec/19); exposure (Jan/2013) } \\
\hline Sensitivity analysis 2 & 413,027 & $2,519,465$ & 232.24 \\
\hline \multicolumn{4}{|l|}{ Period (Jan/08 - Dec/19); exposure (Feb/2013) } \\
\hline Sensitivity analysis 3 & 378,473 & $2,308,685$ & 212.81 \\
\hline \multicolumn{4}{|l|}{ Period (Mar/08 - Dec/19); exposure (Dec/2012) } \\
\hline Sensitivity analysis 4 & 312,953 & $1,909,013$ & 175.97 \\
\hline \multicolumn{4}{|l|}{ Period (Mar/08 - Dec/19); exposure (Jan/2013) } \\
\hline Sensitivity analysis 5 & 360,127 & $2,196,775$ & 202.49 \\
\hline Period (Mar/08 - Dec/19); exposure (Feb/2013) & & & \\
\hline
\end{tabular}

\section{Discussion}


Our study showed that the new zero-tolerance drinking and driving law (Law 12760) has significantly reduced hospitalization rates for land transport accidents in Brazil. These results stand in agreement with subgroup analyses for the Brazilian regions, although north and northeast regions did not immediately reduce hospitalization rates (level change). Moreover, land transport accidents are more common among young males in both absolute and relative (incidence rate) values.

Other studies have also reported worse results for the north and northeast related to mortality for road traffic accidents compared to other regions (30-32). These results are also in line with data from the National Health Survey undertaken in Brazil in 2019, from which north and northeast presented the highest drinking and driving prevalence among the Brazilian regions, reaching 23.4 and $21.5 \%$ of their inhabitants, respectively (33). Taking the country as a whole, Brazil has reduced the drinking and driving prevalence from $24.4 \%$ in 2013 to $17.0 \%$ in 2019 (33).

In Brazil, hospitalizations for land transport accidents corresponded to 15.8\% of all hospital admissions for external causes in 2011. Males have a 3.8-fold higher chance of being involved in an accident than females (4). In general, males (27.3\%) self-reported having more episodes of driving vehicles after drinking alcohol than women (7.1\%), as reported in the Second National Survey on Alcohol and Drugs, 2012 (34).

A similar finding, in 2013, among the victims of land transport accidents undergoing hospitalization in public hospitals or those affiliated with the SUS, there was a predominance of male individuals, young adults and motorcyclists living in the mid-west and northeast regions of Brazil (35). One possible explanation for this finding is the fact that, culturally, men are more exposed to dangerous situations, such as alcohol consumption and driving a motor vehicle at speeds higher than those allowed on the roads (35).

\section{Strengths and limitations}

We investigated a large time series (144 time units) using a quasi-experimental approach to estimate the effect of a new zero-tolerance drinking and driving law on the hospital rate for land transport accidents in Brazil. Most studies have investigated mortality data (36). To the best of our knowledge, our study is the first attempt to provide estimates of the hospitalization rate. This outcome is important since it impacts costs and available hospital beds in the public health system. We have also relied on a rich administrative database, from which the Ministry of Health reimburses hospital services across the country.

However, it is worth noting several limitations of our study. First, our estimates refer to hospital admissions in the public health system. Approximately $25 \%$ of the Brazilian population has private health insurance. On this basis, our study may underestimate the benefits of the new zero-tolerance law. Second, our preintervention period did not reflect an absence of zero-tolerance drinking and driving law. Law 11705 enacted in June 2008 had already stated most of the legal penalties that Law 12760 enacted in December 2012 did. The difference between them is the law's enforcement, which is much stronger in the latter law. Third, there are several socioeconomic or road safety (poor road infrastructure and/or safety conditions related to vehicles) disparities between and within the Brazilian regions, which may influence drivers' perceptions of law enforcement.

\section{Implications for policies}

Since Law 12760 was enacted on December 2012, Brazil has adopted a hard-line stance against those driving under any influence of alcohol, particularly by increasing the use of sobriety checkpoints and including other evidence to prove drivers' intoxication (driver's appearance and actions at the scene). Our estimates indicated that over 400,000 hospitalizations for land transport accidents were averted by the law during a 7-year period, corresponding to a reduction of Int\$ 245 in inpatient care for the same period. The was also a positive externality to reallocate the hospital days to other health conditions or diseases based on the averted hospitalization for land traffic accidents.

Thinking globally, a stricter zero-tolerance drinking and driving law may be a good value for money for low- and middle-income countries, since its implementation appears to be at low cost. However, decision makers must ensure that the law would change drivers' perception about the legal consequences of being caught driving under any influence of alcohol. For that, local governments must implement frequent and random checkpoints around cities, particularly in areas with a higher incidence of land transport accidents. The media has a central role in disseminating news on the public effort to tackle drinking and driving cases.

\section{Declarations}

\section{Contributions:}

- Conception and design of the work: CRLS, LXR, ENS.

- Analysis: CRLS, LXR.

- Interpretation of data for the work: CRLS, LXR, ENS.

- Drafting the work: CRLS, ENS.

- Revising it critically: CRLS, LXR, ENS.

- Final approval of the version to be published: CRLS, LXR, ENS.

\section{Conflict of interest}

None declared.

\section{References}


1. WHO. Global Status Report on Road Safety 2018 [Internet]. Vol. 66, International Reviews of Immunology. 2018. 1-15 p. Available from: https://doi.org/10.3109/08830185.2014.902452\%0Ahttps://www.bertelsmann-

stiftung.de/fileadmin/files/BSt/Publikationen/GrauePublikationen/MT_Globalization_Report_2018.pdf\%0Ahttp://eprints.Ise.ac.uk/43447/1/India_globalis society and inequalities $\% 28$

2. Salgado, R., de Campos, S., Duailibi, V. R. \& Laranjeira, S. RR. O impacto da "Lei Seca" sobre o beber e dirigir em belo horizonte/MG. Cienc e Saude Coletiva, 17 (4), 971-976 (2012).

3. Campos, V. R. et al. The effect of the new traffic law on drinking and driving in São Paulo, Brazil. Accid Anal Prev, 50, 622-627 (2013).

4. Mascarenhas, M. D. M. \& De Azevedo Barros, M. B. Characterization of hospitalizations due to external causes in the public health system, Brazil, 2011. Rev Bras Epidemiol, 18 (4), 771-784 (2015).

5. Lozano, R. et al. Measuring progress from 1990 to 2017 and projecting attainment to 2030 of the health-related Sustainable Development Goals for 195 countries and territories: a systematic analysis for the Global Burden of Disease Study 2017., 392 (10159), 2091-2138 (2018).

6. Lefio, Ã., Bachelet, V. C., Jiménez-Paneque, R., Gomolán, P. \& Rivas, K. A systematic review of the effectiveness of interventions to reduce motor vehicle crashes and their injuries among the general and working populations.Rev Panam Salud Publica/Pan Am J Public Heal. $2018 ; 42$.

7. WHO. A Road Safety Technical Package [Internet] \& Save, L. I. V. E. S. 2017. 60 p. Available from:

http://iris.paho.org/xmlui/bitstream/handle/123456789/34980/9789275320013-por.pdf?sequence=1\&isAllowed=y

8. WHO. Global status report on road safety [Internet]. Injury prevention. 2015. Available from: https://www.who.int/violence_injury_prevention/road_safety_status/2015/Section_2_GSRRS2015.pdf

9. Haghpanahan, H. et al. An evaluation of the effects of lowering blood alcohol concentration limits for drivers on the rates of road traffic accidents and alcohol consumption: a natural experiment. Lancet (London, England), 393 (10169), 321-329 (2019 Jan).

10. Burton, R. et al. A rapid evidence review of the effectiveness and cost-effectiveness of alcohol control policies: an English perspective., 389 (10078), 1558-1580 (2017).

11. Brasil Lei $n^{\circ} 11.705$, de 19 de Junho de 2008. [Internet]. Diário Oficial da União. 2008. Available from: file://C:/Users/Usuario/Desktop/doutorado/tese/artigos para ler/lei seca.html

12. Jomar, R. T., Ramos, D., de Fonseca, O., de O, V. A. \& Junger, W. L. Effect of the zero-tolerance drinking and driving law on mortality due to road traffic accidents according to the type of victim, sex, and age in Rio de Janeiro, Brazil: An interrupted time series study. Traffic Inj Prev, 20 (3), $227-232$ (2019).

13. Nunes, H. R., de C, Murta-Nascimento, C. \& Lima, M. C. P. Impacto da Lei Seca sobre a mortalidade no trânsito nas unidades federativas do Brasil: uma análise de série temporal interrompida.Rev Bras Epidemiol. 2021;24.

14. Abreu, D. R., de OM, E. M. \& de Mathias, T. A. F. Impact of the brazilian traffic code and the law against drinking and driving on mortality from motor vehicle accidents.Cad Saude Publica. 2018;34(8).

15. IBGE. Área territorial brasileira (IBGE, Rio de Janeiro, 2018).

16. Brasil Rodovias Federais. 2019.

17. IBGE. Frota de veículos.

18. Da Silva, E. N. \& Powell-Jackson, T. Does expanding primary healthcare improve hospital efficiency? Evidence from a panel analysis of avoidable hospitalisations in 5506 municipalities in Brazil, 2000-2014.BMJ Glob Heal. 2017;2(2).

19. Massuda, A., Hone, T., Leles, F. A. G., De Castro, M. C. \& Atun, R. The Brazilian health system at crossroads: Progress, crisis and resilience.BMJ Glob Heal. 2018;3(4).

20. Cellarius, L. O Código de Trânsito Brasileiro, a "Lei Seca", e a discussão sobre a aplicação das medidas administrativas e sanções penais ao condutor de veículo automotor que recusa realizar os testes de alcoolemia [Internet]. 2013. Available from: https://ambitojuridico.com.br/cadernos/direito-penal/ocodigo-de-transito-brasileiro-a-lei-seca-e-a-discussao-sobre-a-aplicacao-das-medidas-administrativas-e-sancoes-penais-ao-condutor-de-veiculo-automotorque-recusa-realizar-os-testes-de-alcoolemia/

21. DEBS, THIAGO DE CARVALHO \& SIQUEIRA RCDM. LEI SECA Nº 12.760/12 OS EFEITOS JURÍDICOS E SUAS ALTERAÇÕES [Internet]. Goiânia; 2020. Available from: https://repositorio.pucgoias.edu.br/jspui/bitstream/123456789/160/1/Thiago de Carvalho Debs.pdf

22. LORENSON, J., FRIAS AS, AS CONSEQUÊNCIAS JURÍDICAS DA EMBRIAGUES AO VOLANTE FRENTE A NOVA \& LEI SECA. In Paraná: Anais do Simpósio Sustentabilidade e Contemporaneidade nas Ciências Sociais; 2013. p. 6.

23. de Morais Neto, O. L., Silva, M. M. A., de Lima, C. M., Malta, D. C. \& SilvaJr JB da. Projeto Vida no Trânsito: avaliação das ações em cinco capitais brasileiras, 2011-2012. Epidemiol e Serviços Saúde. 2013;22(3):373-82.

24. Brasil \& LEI No 9.503, DE 23 DE SETEMBRO DE. 1997. Texto compilado. Institui o Código de Trânsito Brasileiro. [Internet]. 1997. Available from: https://www.planalto.gov.br/ccivil_03/leis/I9503.htm\#art270§4

25. Brasil, M. da S. Banco de dados do Sistema Único de Saúde-DATASUS, Sistema de Informações Hospitalares [Internet]. Available from: http://www2.datasus.gov.br/DATASUS/index.php?area=060502

26. Kontopantelis, E., Doran, T., Springate, D. A., Buchan, I. \& Reeves, D. Regression based quasi-experimental approach when randomisation is not an option: Interrupted time series analysis.BMJ. 2015;350.

27. Cumby, R. E. \& Huizinga, J. Testing the Autocorrelation Structure of Disturbances in Ordinary Least Squares and Instrumental Variables Regressions. Econometrica, 60 (1), 185 (1992).

28. Wooldrigde, J. M. Introductory Econometrics. A modern approach. Economic Analysis. 2006.

Page $7 / 9$ 
29. Brasil. Resolução no 510, de 07 de abril de 2016. Dispõe sobre as normas aplicáveis a pesquisas em Ciências Humanas e Sociais (Diário Oficial República Federativa do Brasil,. Brasília, 2016).

30. Barroso Junior, G. T., Bertho, A. C. S. \& Veiga, A. de C. a Letalidade Dos Acidentes De Trânsito Nas Rodovias Federais Brasileiras. Rev Bras Estud Popul, 36, 1-22 (2019).

31. Duarte, M. B., Santos, A. B. B. V. \& Sobral, F. C. M. Mortalidade por acidentes de trânsito em idosos nas regiões do Brasil no período de 2009 a 2018. Práticas e Cuid Rev Saúde Coletiva [Internet]. 2021;2(e10392):1-13. Available from:

https://www.revistas.uneb.br/index.php/saudecoletiva/article/view/10392/7525

32. Duarte, E. C., Tauil, P. L., Duarte, E., Sousa, M. C. \& Monteiro, R. A. Mortalidade por acidentes de transporte terrestre e homicídios em homens jovens das capitais das Regiões Norte e Centro-Oeste do Brasil, 1980-2005. Epidemiol e Serviços Saúde. 2008;17(1).

33. IBGE. Pesquisa Nacional de Saúde 2019. 2020.

34. Brasil II Levantamento Nacional de Álcool e Drogas (LENAD) - 2012 [Internet]. São Paulo; 2014. Available from: https://inpad.org.br/wpcontent/uploads/2014/03/Lenad-II-Relatório.pdf

35. Andrade, S. S. C. \& de Jorge, A. M. Hospitalization due to road traffic injuries in Brazil, 2013: hospital stay and costs. Epidemiol serv saúde, 26 (1), $31-38$ (2017).

36. Ying, Y. H., Wu, C. C. \& Chang, K. The effectiveness of drinking and driving policies for different alcohol-related fatalities: A quantile regression analysis. Int J Environ Res Public Health, 10 (10), 4628-4644 (2013).

\section{Figures}

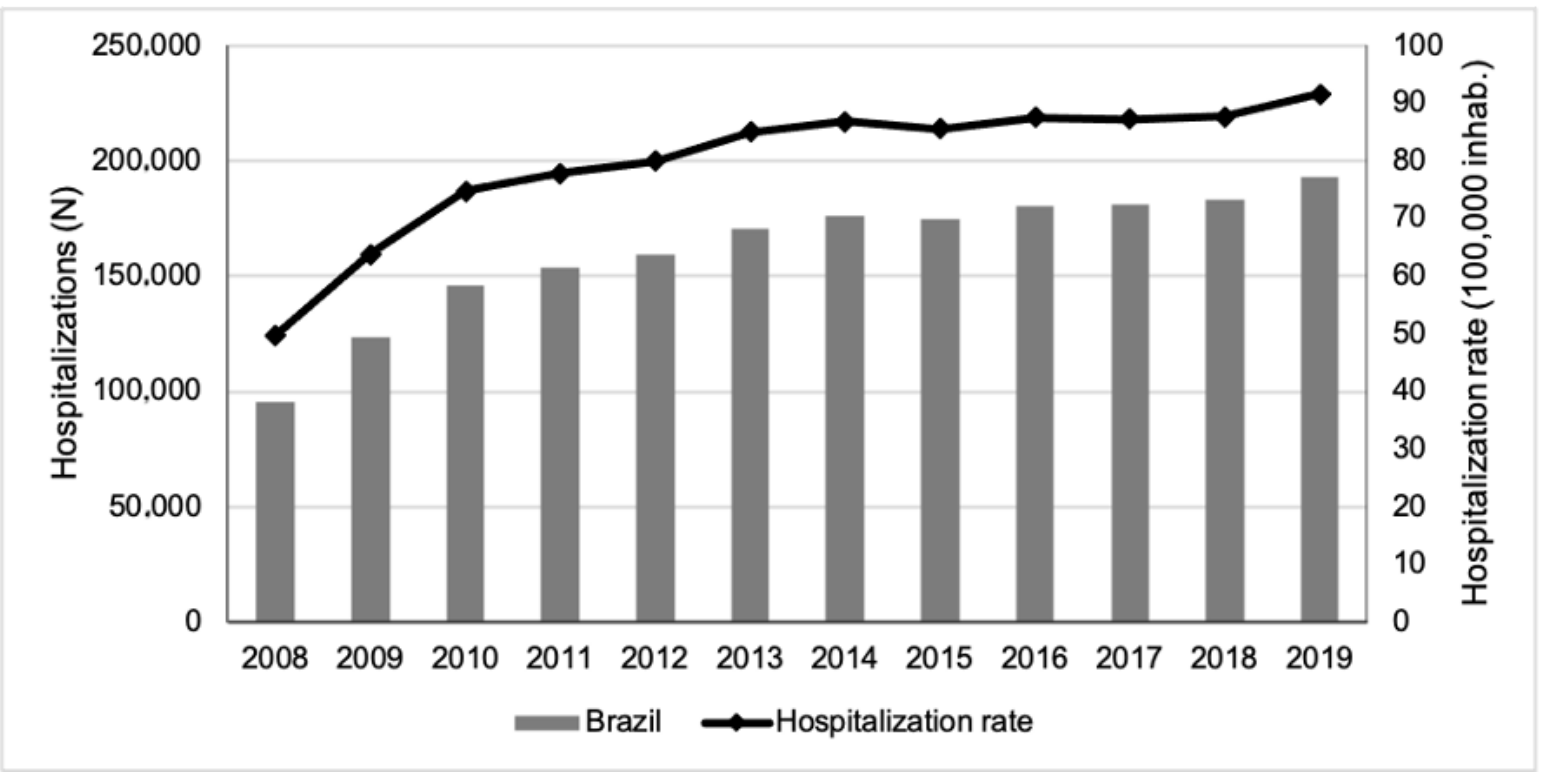

\section{Figure 1}

Trend in hospitalizations for land transport accidents (absolute and rate per 100,000 inhabitants) from 2008 to 2019, Brazil 
(a)

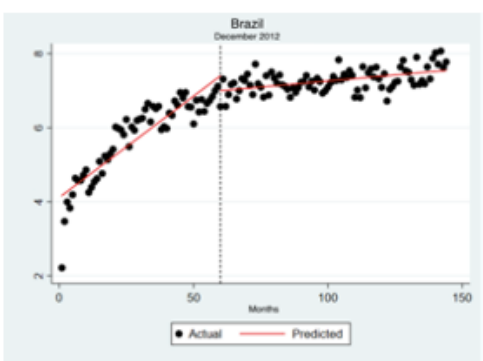

(c)

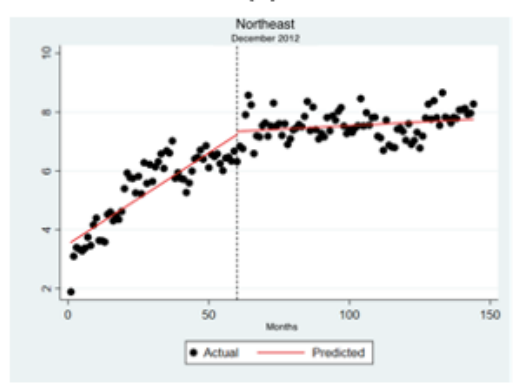

(e)

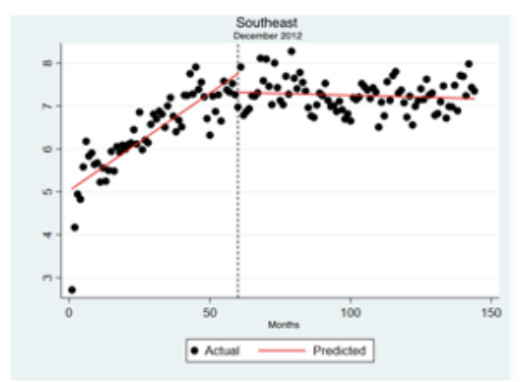

(b)

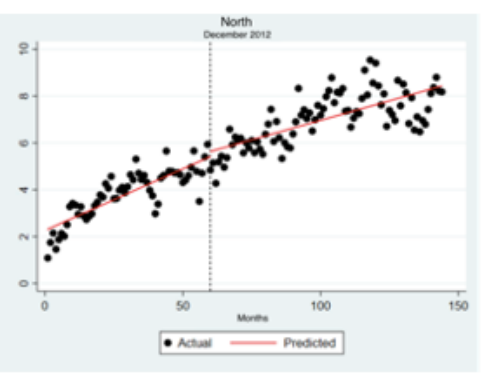

(d)

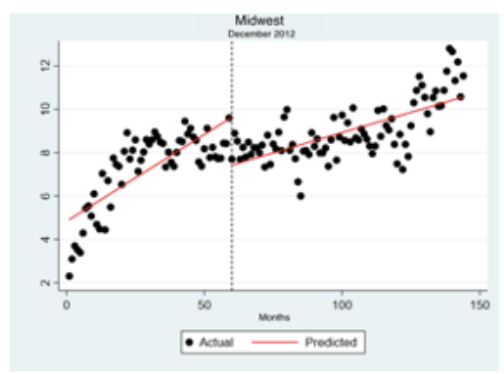

(f)

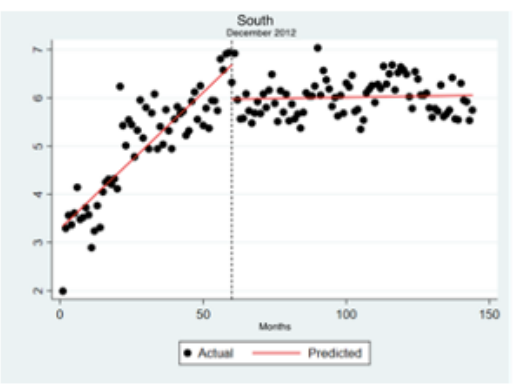

Figure 2

Graphical representation of the zero-tolerance drinking and driving law on hospital rate for land transport accidents from interrupted time series regression for Brazil (a) and its regions (b-f), 2008-2019.

\section{Supplementary Files}

This is a list of supplementary files associated with this preprint. Click to download.

- Supplementarymaterial.docx 